\title{
GAMBARAN PENGETAHUAN PARAJI TENTANG PERAN PARAJI DALAM BERMITRA DENGAN BIDAN DI WILAYAH KERJA PUSKESMAS DTP RANCAEKEK KABUPATEN BANDUNG
}

\author{
Damai Yanti ${ }^{1}$, Wida Nengsih ${ }^{2}$ \\ Kebidanan, STIKES Budi Luhur Cimahi Jawa Barat \\ E-mail: royasmile@yahoo.com
}

\begin{abstract}
Abstrack
This research is research deskriftif to know the image of knowledge about the role of paraji in an effort is working in partnership with the midwife in the work area of puskesmas DTP Rancaekek Kabupaten Bandung with a sample 28 people, Where the sample overall sampling techniques. Statistical analysis that is used is univariat. Data collection done through the distribution of kuisione. Based on research in the work area community health centers DTP Rancaekek Obtained the result is more than half of respondents be in the knowledge that the enough 21 people (75,0\%), Less than half the respondents in lacking knowledge by 4 people (14,3\%), So that it can be concluded that the effort the knowledge in the work area the DTP Rancaekek, enough in category because the majority of respondents undergo training conducted by the regular and continuous.
\end{abstract}

Keywords: Paraji role, midwife

\begin{abstract}
ABSTRAK
Penelitian ini adalah penelitian deskriftif untuk mengetahui gambaran pengetahuan paraji tentang peran paraji dalam bermitra dengan bidan di Wilayah Kerja Puskesmas DTP Rancaekek Kabupaten Bandung dengan sampel 28 orang, dimana teknik pengambilan sample secara total sampling. Analisis statistik yang digunakan adalah univariat. Pengumpulan data dilakukan melalui penyebaran kuisioner. Berdasarkan hasil penelitian di Wilayah Kerja Puskesmas DTP Rancaekek didapatkan hasilnya adalah lebih dari setengah responden berada dalam tingkat pengetahuan cukup yaitu 21 orang $(75,0 \%)$, kurang dari setengah responden berada dalam pengetahuan kurang yaitu sebanyak 4 orang $(14,3 \%)$, dan sebagian kecil responden berada dalam tingkat pengetahuan baik sebanyak 3 orang $(10,7 \%)$. Sehingga dapat disimpulkan bahwa tingkat pengetahuan paraji di Wilayah Kerja Puskesmas DTP Rancaekek berada pada kategori cukup, karena sebagian besar responden mengikuti pembinaan yang dilakukan oleh puskesmas secara rutin dan terus menerus.
\end{abstract}

Kata Kunci: Peran paraji, bidan 


\section{PENDAHULUAN}

Angka kematian ibu (AKI) merupakan barometer pelayanan kesehatan di suatu negara. Bila angka kematian ibu masih tinggi berarti pelayanan kesehatan ibu belum optimal. Sebaliknya bila AKI rendah berarti pelayanan kesehatan ibu sudah baik. Tingginya AKI di Indonesia menempatkan upaya penurunan AKI sebagai prioritas.

Angka kematian Ibu (AKI) di Indonesia merupakan angka tertinggi di kawasan Asia Tenggara. AKI di propinsi Jawa Barat sendiri mencapai 724 kasus pada tahun 2008. Untuk kasus kematian bayi, pada tahun 2008 ditemukan sebanyak 41 kasus di Jawa Barat dari 165 kasus di seluruh Indonesia, dimana $60,98 \%$ persalinan ditolong oleh paraji (Depkes RI, 2009).

Pertolongan persalinan oleh paraji menurut WHO relatif masih tinggi yaitu sekitar $70 \%$ sampai $80 \%$. Di Indonesia pertolongan persalinan oleh paraji sebesar $40 \%$, sedangkan pada tahun 2008 angka persalinan di tolong oleh non kesehatan di Jawa Barat sebesar 123.220 atau sekitar 12,56\% dan untuk tahun 2010 mengalami peningkatan menjadi $36 \%$ persalinan di tolong oleh non kesehatan. (Saifuddin, 2006).

Penyebab kematian ibu di Jawa Barat, salah satunya adalah keterlambatan mendapat pertolongan karena hambatan geografis dan transfortasi untuk akses terhadap layanan kesehatan dan hanya $64 \%$ desa ada bidan tetapi 100\% desa ada paraji, perbandingan jumlah bidan desa dengan paraji 4:1 ( Retnasih, 2004).

Persalinan merupakan kejadian fisiologis yang prosesnya dapat berjalan dengan aman jika penolong persalinan dapat memantau persalinan untuk mendeteksi dini terjadinya komplikasi. Tenaga paraji sejak dahulu kala sampai sekarang merupakan pemegang peranan penting dalam pelayanan kebidanan. Dalam lingkungan, paraji merupakan tenaga terpercaya dalam segala soal yang terkait dengan reproduksi wanita. Pertolongan persalinan oleh paraji (Dukun bayi).

Dukun bayi adalah seorang wanita berumur \pm 40 tahun ke atas, pengetahuan tentang fisiologis dan patologis dalam kehamilan, persalinan, serta nifas sangat terbatas oleh karena itu apabila terjadi komplikasi sering kali tidak mampu mengatasinya, dukun bayi menolong persalinan berdasarkan pengalaman dan kurang professional. Sehingga sering terjadi kecacatan bahkan terjadi kematian ibu dan bayi (Prawirohardjo, 2005).

Dalam usaha meningkatkan pelayanan kebidanan dan kesehatan ibu dan anak maka tenaga kesehatan seperti bidan harus kerjasama dengan paraji untuk melakukan pelatihan dengan harapan dapat meningkatkan kemampuan dalam menolong persalinan, selain itu dapat mengenal tanda- tanda bahaya dalam kehamilan dan persalinan dan segera meminta pertolongan pada bidan. Dukun bayi yang ada harus ditingkatkan kemampuannya, tetapi bidan tidak dapat bekerjasama dengan dukun bayi dalam mengurangi angka kematian dan angka kesakitan (Prawirohardjo,2005).

Keberadaan paraji sebagai orang kepercayaan dalam menolong persalinan, sangat dibutuhkan keberadaannya oleh masyarakat. Berbeda dengan keberadaan bidan yang rata-rata masih muda dan belum seluruhnya mendapatkan kepercayaan dari masyarakat. Sehingga perlu dicari suatu kegiatan yang dapat membuat 
kerjasama yang saling menguntungkan antara bidan dan paraji, dengan harapan pertolongan persalinan akan berpindah dari paraji ke bidan. Dengan demikian, kematian ibu dan bayi diharapkan dapat diturunkan dengan mengurangi resiko yang mungkin terjadi bila persalinan ditolong oleh tenaga kesehatan yang kompeten dengan menggunakan pola kemitraan bidan dan paraji.

Menurut data yang diperoleh dari Puskesmas DTP Rancaekek Kabupaten Bandung terdapat 28 orang paraji, dan terdapat jumlah kematian ibu pada tahun 2008 yaitu1 orang. Adapun jumlah kematian bayi dan neonatus pada tahun 2013 yaitu 1 kematian. Pertolongan persalinan yang ditolong oleh tenaga kesehatan pada tahun 2009 yaitu $46 \%, 54 \%$ ditolong non kesehatan (paraji) dan yang ditolong oleh tenaga kesehatan pada tahun 2010 yaitu $60 \%, 40 \%$ ditolong non kesehatan (paraji). Hal ini sangat jauh dari target yang telah ditetapkan yaitu $95 \%$.

Pada tanggal 1 April 2014 peneliti melakukan studi pendahuluan terhadap 8 orang paraji, didapatkan hasil yaitu 3 orang dari 8 paraji mengetahui peran paraji dalam kemitraan dengan bidan dan 5 orang dari 8 paraji tidak mengetahui tentang peran paraji dalam kemitraan dengan bidan. Dari jumlah paraji 28 orang.

Metode penelitian Penelitian ini dilaksanakan dengan menggunakan metode penelitian survey secara cross sectional suatu penelitian untuk mempelajari dinamika korelasi antara faktor resiko dengan efek, dengan cara pendekatan, observasi atau pengumpulan data sekaligus pada suatu saat dan bersifat deskriptif dimana hasil disajikan dalam bentuk tabel
frekuensi.Variabel yang digunakan dalam penelitian ini adalah pengetahuan paraji dalam bermitra dengan bidan.Populasi dalam penelitian ini adalah seluruh paraji yang ada di Wilayah Kerja Puskesmas DTP Rancaekek yang berjumlah 28 orang. Dari jumlah 28 orang paraji tersebut 10 orang masih aktif melakukan pertolongan persalinan sendiri. Penelitian ini mengambil sampel dengan caraTotal Sampling, yaitu cara pengambilan sampel yang dilakukan secara keseluruhan berjumlah 28 orang, berdasarkan jumlah populasi yang ada di Wilayah Kerja Puskesmas DTP Rancaekek Kabupaten Bandung Tahun 2014. Untuk mengetahui pengetahuan responden digunakan angket dengan penilaian untuk setiap jawaban yang benar diberi nilai 1 dan yang salah diberi nilai 0 . Setelah diperoleh hasil dengan cara perhitungan seperti diatas, kemudian nilai akhir tersebut dimasukan kedalam beberapa kategori dengan mengacu kepada :

a. Kategori baik apabila $76-100 \%$

b. Kategori cukup apabila 56-75\%

c. Kategori kurang apabila $\leq 55 \%$

\section{HASIL}

Gambaran pengetahuan paraji tentang peran paraji dalam bermitra dengan bidan di Wilayah Kerja Puskesmas DTP Rancaekek.

Gambaran pengetahuan paraji tentang peran paraji dalam bermitra dengan bidan dapat dilihat dari tabel berikut :

Tabel 1. Distribusi Frekuensi Gambaran Pengetahuan Paraji Tentang Peran Paraji Dalam Bermitra Dengan Bidan di Wilayah Kerja Puskesmas DTP Rancaekek Kabupaten Bandung

\begin{tabular}{lcc}
\hline Tingkat & Frekuensi & Persentase (\%) \\
Pengetahuan & 3 & 10,7
\end{tabular}




\begin{tabular}{lcc} 
Cukup & 21 & 75,0 \\
Kurang & 4 & 14,3 \\
\hline Jumlah & 28 & 100 \\
\hline
\end{tabular}

(Sumber : Hasil Wawancara penelitian di Wilayah

Kerja Puskesmas DTP Rancaekek Kabupaten Bandung).

Berdasarkan data pada tabel 1 diatas dapat dilihat bahwa tingkat pengetahuan paraji tentang peran paraji dalam bermitra dengan bidan lebih dari setengah responden berada dalam tingkat pengetahuan cukup yaitu sebanyak 21 orang $(75,0 \%)$, kurang dari setengah responden responden berada dalam tingkat pengetahuan kurang yaitu sebanyak 4 orang $(14,3 \%)$, dan sebagian kecil responden berada dalam tingkat pengetahuan baik sebanyak 3 orang $(10,7 \%)$.

1. Gambaran pengetahuan paraji tentang peran paraji dalam bermitra berdasarkan peran paraji dalam pelayanan kebidanan, pemeriksaan dan pemantauan, pelayanan persalinan, dan perawatan ibu dan bayi pada masa nifas, yaitu sebagai berikut :

a. Gambaran pengetahuan paraji tentang peran paraji dalam pelayanan kebidanan

Gambaran pengetahuan paraji tentang peran paraji dalam pelayanan kebidanan, dapat dilihat dari tabel berikut :

Tabel 2. Distribusi Frekuensi Gambaran Pengetahuan Paraji Tentang Peran Paraji dalam Pelayanan Kebidanan di Wilayah Kerja Puskesmas DTP Rancaekek Kabupaten Bandung Tahun

\begin{tabular}{lcc}
\hline $\begin{array}{l}\text { Tingkat } \\
\text { Pengetahuan }\end{array}$ & Frekuensi & $\begin{array}{c}\text { Persentase } \\
(\%)\end{array}$ \\
\hline Baik & 3 & 10,7 \\
Cukup & 7 & 25,0 \\
Kurang & 18 & 64,3 \\
\hline Jumlah & 28 & 100 \\
\hline
\end{tabular}

(Sumber : Hasil Wawancara penelitian di Wilayah Kerja Puskesmas DTP Rancaekek Kabupaten Bandung).

Berdasarkan data pada tabel 2 diatas dapat dilihat bahwa tingkat pengetahuan paraji tentang peran paraji dalam bermitra dengan bidan, lebih dari setengah responden berada dalam tingkat pengetahaun kurang yaitu sebanyak 18orang $(64,3 \%)$, kurang dari setengah responden berada dalam tingkat pengetahuan cukup yaitu sebanyak 7 orang $(25,0 \%)$, dan sebagian kecil responden berada dalam tingkat pengetahuan baik yaitu sebanyak 3 orang $(10,7 \%)$.

b. Gambaran pengetahuan paraji tentang peran paraji dalam pemantauan dan pemeriksaan kehamilan

Gambaran pengetahuan paraji tentang peran paraji dalam pemantauan dan pemeriksaan kehamilan, dapat dilihat dari tabel berikut :

Tabel 3. Distribusi Frekuensi Gambaran Pengetahuan Paraji Tentang Peran Paraji Dalam Pemantauan dan Pemeriksaan Kehamilan di Wilayah Kerja Puskesmas DTP Rancaekek Kabupaten Bandung.

\begin{tabular}{lcc}
\hline $\begin{array}{l}\text { Tingkat } \\
\text { Pengetahuan }\end{array}$ & Frekuensi & $\begin{array}{c}\text { Persentase } \\
(\%)\end{array}$ \\
\hline Baik & 7 & 25,0 \\
Cukup & 15 & 53,6 \\
Kurang & 6 & 21,4 \\
\hline Jumlah & 28 & 100 \\
\hline
\end{tabular}

(Sumber : Hasil Wawancara penelitian di Wilayah Kerja Puskesmas DTP Rancaekek Kabupaten Bandung).

Berdasarkan data pada tabel 3 diatas dapat dilihat bahwa tingkat pengetahuan paraji tentang peran paraji dalam bermitra dengan bidan, lebih dari setengah responden berada dalam tingkat pengetahaun cukup yaitu sebanyak 15 orang 
$(53,6 \%)$, kurang dari setengah responden berada dalam tingkat pengetahuan baik yaitu sebanyak 7 orang $(25,0 \%)$, dan sebagian kecil responden berada dalam tingkat pengetahuan kurang yaitu sebanyak 6 orang $(21,4 \%)$.

c. Gambaran pengetahuan paraji tentang peran paraji dalam pelayanan persalinan

Gambaran pengetahuan paraji tentang peran paraji dalam pelayanan persalinan, dapat dilihat dari tabel berikut :

Tabel 4. Distribusi Frekuensi Gambaran Pengetahuan Paraji Tentang Peran Paraji dalam Pelayanan Persalinan di Wilayah Kerja Puskesmas DTP Rancaekek Kabupaten Bandung

\begin{tabular}{lcc}
\hline $\begin{array}{l}\text { Tingkat } \\
\text { Pengetahuan }\end{array}$ & Frekuensi & $\begin{array}{c}\text { Persentase } \\
(\%)\end{array}$ \\
\hline Baik & 8 & 28,6 \\
Cukup & 6 & 21,4 \\
Kurang & 14 & 50,0 \\
\hline Jumlah & 28 & 100
\end{tabular}

(Sumber : Hasil Wawancara penelitian di Wilayah Kerja Puskesmas DTP Rancaekek Kabupaten Bandung).

Berdasarkan data pada tabel 4 diatas dapat dilihat bahwa tingkat pengetahuan paraji tentang peran paraji dalam bermitra dengan bidan setengah dari responden berada dalam tingkat pengetahuan kurang yaitu sebanyak 14 orang $(50,0 \%)$, kurang dari setengah responden berada dalam tingkat pengetahuan baik yaitu sebanyak 8 orang $(28,6 \%)$, dan sebagian kecil responden berada dalam tingkat pengetahuan cukup yaitu sebanyak 6 orang $(21,4 \%)$.

d. Gambaran pengetahuan paraji tentang peran paraji dalam perawatan ibu dan bayi pada masa nifas
Gambaran pengetahuan paraji tentang peran paraji dalam perawatan ibu dan bayi pada masa nifas, dapat dilihat dari tabel berikut :

Tabel 5 Distribusi Frekuensi Gambaran Pengetahuan Paraji Tentang Peran Paraji Dalam Pelayanan Ibu dan Bayi pada Masa Nifas di Wilayah Kerja Puskesmas DTP Rancaekek Kabupaten Bandung.

\begin{tabular}{lcc}
\hline $\begin{array}{l}\text { Tingkat } \\
\text { Pengetahuan }\end{array}$ & Frekuensi & $\begin{array}{c}\text { Persentase } \\
(\%)\end{array}$ \\
\hline Baik & 4 & 14,3 \\
Cukup & 21 & 75,0 \\
Kurang & 3 & 10,7 \\
\hline Jumlah & 28 & 100
\end{tabular}

(Sumber : Hasil Wawancara penelitian di Wilayah Kerja Puskesmas DTP Rancaekek Kabupaten Bandung).

Berdasarkan data pada tabel 5 diatas dapat dilihat bahwa tingkat pengetahuan paraji tentang peran paraji dalam bermitra dengan bidan lebih dari setengah responden berada dalam tingkat pengetahuan cukup yaitu 21 orang $(75,0 \%)$, sebagian kecil responden tingkat pengetahuan baik yaitu sebanyak 4 orang (14,3\%), dan sebagian kecil responden tingkat pengetahuan kurang yaitu 3 orang $(10,7 \%)$.

\section{PEMBAHASAN}

1. Gambaran pengetahuan paraji tentang peran paraji dalam bermitra dengan bidan di Wilayah Kerja Puskesmas DTP Rancaekek Kabupaten Bandung tahun 2014 didapat lebih dari setengah responden berada dalam tingkat pengetahuan cukup yaitu sebanyak 21 orang (75,0\%), kurang dari setengah responden berada dalam tingkat pengetahuan kurang yaitu 
sebanyak 4 orang $(14,3 \%)$, dan sebagian kecil responden berada dalam tingkat pengetahuan baik yaitu sebanyak 3 orang $(10,7 \%)$.

Pengetahuan paraji cukup karena $75 \%$ dari paraji yang berada di Wilayah Kerja Puskesmas DTP Rancaekek mengikuti pembinaan yang dilakukan oleh Puskesmas DTP Rancaekek secara terus menerus.

2. Gambaran pengetahuan paraji tentang peran paraji dalam bermitra dengan bidan di Wilayah Kerja Puskesmas DTP Rancaekek Kabupaten Bandung tahun 2014 tentang pelayanan kebidanan, pemeriksaan dan pemantauan kehamilan, pelayanan persalinan dan perawatan ibu dan bayi pada masa nifas adalah :

a. Pengetahuan paraji tentang peran paraji dalam pelayanan kebidanan

Berdasarkan tabel 4.2 tentang pengetahuan paraji dalam pelayanan kebidanan didapat hasil lebih dari setengah responden berada dalam tingkat pengetahuan kurang yaitu sebanyak 18 orang $(64,3 \%)$.

Kemungkinan hal ini disebabkan karena paraji kurang mendapat informasi dari bidan yang berada di wilayahnya walaupun sudah ada pembinaan bagi paraji, namun paraji jarang hadir bahkan ada yang tidak hadir dikarenakan jarak dari tempat tinggal paraji ke puskesmas jauh dan memerlukan biaya yang mahal, sehingga pembinaan yang diterima tidak secara rutin.

Hal tersebut sesuai dengan teori dimana menurut (Retnasih, 2004) bahwa pembinaan harus dilakukan secara teratur ataupun terus-menerus dan berkesinambungan untuk mencapai tujuan yaitu paraji mengetahui dan terampil dalam cara menolong persalinan secara aman dan dalam perawatan ibu dan anak, sedangkan jika pembinaan tidak dilaksanakan secara berkesinambungan maka pencapaian tujuan tidak akan terlaksana.

\section{b. Pengetahuan paraji tentang peran paraji dalam pemeriksaan dan pemantauan kehamilan}

Berdasarkan tabel 4.3 tentang pengetahuan paraji dalam pemeriksaan dan pemantauan kehamilan didapat hasil lebih dari setengah responden berada dalam tingkat pengetahuan cukup yaitu sebanyak 15 orang $(53,6 \%)$

Dari hasil penelitian diatas maka dapat dilihat bahwa pengetahuan paraji tentang peran paraji dalam pemeriksaan dan pemantauan kehamilan adalah cukup. Hal ini dikarenakan sebagian paraji telah bermitra dengan bidan sehingga paraji mendapat informasi dari bidan tentang faktor resiko dalam kehamilan, persalinan, masa nifas dan faktor resiko bayi baru lahir Selain itu, paraji mendapat pengetahuan dari kader kesehatan diwilayahnya yang aktif memberi informasi tentang kesehatan.

Hal ini sesuai dengan teori menurut (Retnasih, 2004) bahwa manfaat kemitraan bagi dukun paraji adalah memperoleh pengetahuan tentang kesehatan pada umumnya dan pada khususnya memperoleh pengetahuan tentang kesehatan ibu dan anak.

\section{c. Pengetahuan paraji tentang peran paraji dalam pelayanan persalinan}

Berdasarkan tabel 4.4 tentang pengetahuan paraji dalam pelayanan persalinan didapat hasil setengah dari responden berada 
dalam tingkat pengetahuan kurang yaitu sebanyak 14 orang $(50,0 \%)$.

Dari hasil penelitian diatas masih terdapat paraji yang tidak mengetahui cara pencegahan infeksi saat proses persalinan, seperti membersihkan gunting dan proses sterilisasi alatalat harus direbus pada air mendidih selama 10 menit dan ada paraji yang masih belum tahu bahwa bayi baru lahir tidak boleh langsung dimandikan tetapi setelah enam jam kelahiran baru boleh dimandikan untuk mencegah hilangnya panas tubuh pada bayi baru lahir dan kurangnya hubungan antar bidan dan paraji yang mempunyai pengetahuan kurang.

Hal ini sesuai dengan teori (Retnasih, 2004) bahwa landasan kemitraan salah satunya adalah dengan saling menghubungi sehingga terjalin hubungan yang erat dan harmonis dan paraji dapat mendapatkan informasi tentang kesehatan ibu dan anak dengan mudah.

\section{d. Pengetahuan paraji tentang peran paraji dalam pelayanan ibu masa nifas dan bayi.}

Berdasarkan tabel 4.5 tentang pengetahuan paraji dalam pelayanan ibu masa nifas dan bayi didapat hasil lebih dari setengah responden berada dalam tingkat pengetahuan cukup yaitu 21 orang $(75,0 \%)$.

Hal ini menunjukkan bahwa lebih dari setengah responden telah mengetahui peran paraji dalam pelayanan ibu masa nifas dan bayi. Karena sebagian paraji telah bermitra dan mendapatkan informasi dari tenaga kesehatan dan kader, sedangkan sebagian paraji yang tidak mengetahui perannya dalam pelayanan ibu dan bayi disebabkan paraji tidak mendapat informasi dari tenaga kesehatan karena tidak aktif ataupun karena tidak menghadiri pembinaan paraji disebabkan jarak dan keadaan geografis sehingga membutuhkan biaya yang mahal untuk mendapatkan informasi.

Hal ini sesuai dengan teori menurut (Notoatmodjo, 2005), bahwa individu yang tidak mendapatkan pelatihan dan pembinaan memiliki tingkat keterampilan dan pengetahuan yang berbeda dengan individu yang sudah mengikuti pelatihan satu sampai tiga kali.

\section{KESIMPULAN}

Berdasarkan hasil penelitian ini didapatkan tingkat pengetahuan paraji di Wilayah Kerja Puskesmas DTP Rancaekek berada pada kategori cukup, karena sebagian besar responden mengikuti pembinaan yang dilakukan oleh puskesmas secara rutin dan terus menerus.

\section{SARAN}

Diharapkan dengan adanya penelitian ini paraji dapat memperoleh pengetahuan tentang peran paraji dalam bermitra dengan bidan sehingga mengetahui dan memahami kedudukan, tugas dan fungsinya serta bidan dapat merangkul paraji sehingga paraji dapat berkerjasama.

\section{DAFTAR PUSTAKA}

Arikunto,S.(2002). Prosedur Penelitian Suatu PendekatanPraktis. Jakarta : PT Rineka Cipta.

Arikunto. S. (2006). Prosedur Penelitian Suatu Pendekatan Praktek Edisi V. Jakarta :Rineka Cipta

Dahliani, Lia (2009). Gambaran Pengetahuan Bidan Tentang Partograf. Jakarta 
Depkes RI. (2009). Pedoman PWS KIA. Jakarta : Dirjen Tinkesmas

Dinkes Prov. Jabar. (2006). Kematian Ibu dan Bayi

Masih Tinggi. http://dinkesjabar.go.id.

Diakses tanggal 21 April 2014

Hidayat, Alimul, Aziz. (2007). Metode Penelitian

Kebidanan dan Tekhnik Analisa Data.

Jakarta :Salemba Medika

Hidayat, Aliul, Aziz. (2010). Metode Penelitian

Kebidanan dan Tekhnik Analisis Data.

Jakarta : Salemba Medika

Niken, Meilani. (2009). Kebidanan Komunitas.

Yogyakarta : FITRAMAYA

Notoatmodjo, S. (2006). Metodologi Penelitian

Kesehatan. Jakarta : Rineka Cipta

Notoatmodjo. (2004). Metode Penelitian

Kesehatan.Rineka Cipta: Jakarta

Notoatmodjo . (2005). Ilmu Kesehatan Masyarakat

Prinsip-Prinsip Dasar. Jakarta : Rhineka

Cipta

Notoatmodjo. (2006). Prinsip-Prinsip Dasar Ilmu

Kesehatan Masyarakat. Jakarta : PT

Rineka Cipta

Notoatmodjo .(2007). Kesehatan Masyarakat Ilmu dan Seni. Jakarta : Rineka Cipta

Nursalam.(2004). Konsep Penerapan Metodologi Penelitian Ilmu Keperawatan. Jakarta : Salemba Medika.

Retnasih, Neny. (2004). Pegangan Kader untuk Pembinaan Dukun Paraji dalam Kemitraan Dukun Paraji dan Bidan. Dinas Kesehatan Provinsi Jawa Barat Tahun 2004

Saifudin, dkk. (2005). Buku Acuan Nasional Pelayanan Kesehatan Maternal dan Neonatal.Jakarta : Yayasan Bina Pustaka
Sarwono Prawihardjo bekerjasama dengan JNPKKR-POGI.

Saiful, dkk. (2006). Buku Acuan Nasional Pelayanan KesehatanMaternal dan Noenatal.Jakarta: Yayasan Bina Pustaka

Sugiyono, Dr, Prof. (2011). Metode Penelitian Kuantitatif, Kualitatif dan $R \& B$. Bandung : ALFABETA, cv IKAPI

Syafruddin. (2009). Kebidanan Komunitas. Jakarta : EGC

Wiknjosastro,H,dkk. (2005). Ilmu Kebidanan. Jakarta: Yayasan Bina Pustaka Sarwono Praworihardjo.

Yulifah, Rita. (2009). Asuhan Kebidanan Komunitas. Jakarta : Salemba Medika 